\title{
E-Tilang Web Based Application for Merangin District Traffic Riders
}

Regina Gita Pratiwi ${ }^{1^{*}}$, Max Teja Ajie Cipta Widiyanto (iD?

1. Department of Informatics, Institut Teknology PLN, Jakarta 11750 Indonesia

2. Department of Informatics, Institut Teknology PLN, Jakarta 11750 Indonesia

*reginagitapratiwi@gmail.com(coresponden author)

max@sttpln.ac.id

Article history :

Received : 24 Feb 2021

Accepted : 25 Mar 2021 Available online : 16 Feb 2022

\section{ABSTRACT}

The development of the e-ticketing application starts from planning is identifying problems, the system running, user needs to designing the uml, database and GUI. Up to the coding stage and the application named Electronic Ticketing Application (E-Tilang) Against Traffic Offenders in Merangin Regency is web-based. The application focuses on recording tickets and the results of recording tickets that can be seen on the web. The system created by the author can simplify the process of counting and processing of numbers, both for the Kasatlanas party and the public in seeing the results of the selection trial because all activities are carried out online and the data is recorded in real time in the database.

Keywords : E-tilang, RUP, web.

Journal of Intelligent Computing and Health Informatics is licensed under a Creative Commons Attribution-Share Alike 4.0 International License (CC BY-SA 4.0) 


\section{INTRODUCTION}

Tickets or Proof of Violation are fines imposed by the police on road users who violate regulations. Violations that are often committed are not wearing a helmet, running through traffic lights while it is still red (a vehicle must stop sign) or other violations.

In this era where the digital era is developing rapidly, it should facilitate all aspects of the earth, but it is obvious that not all aspects can enjoy digital development. One of them is the public and the traffic police. Numbering is still done conventionally, causing many queues to occur. A ticket is an example of a violation that is accepted by the community. When the community has received a ticket, many people delay taking care of the administration of the ticket because the community is busy and all administrative processes must be carried out in a designated office. So that there is a lot of fraud from the system, both from the community and the police. So that this system causes the name of the agency or government to become bad in the eyes of the community (Azis \&Utami, 2018).

So that from the above problems, the writer will make an innovation where the conventional ticket becomes eticket which later can be done in the application that has been provided. Which is where in the future it is hoped that this application can facilitate both the public and the police and reduce the extortion that has occurred so far.

\section{METHOD}

\subsection{Rational Unified Process}

The Rational Unified Process (RUP) method is a system development method. Where the RUP has 4 phases of development, first, the inception phase where in this phase determine and analyze problems. Second, the elaboration phase, is the phase where the system design will be made with Unified Modeling Language (UML) (Al-Bahra, 2004; Andre, 2019). Third, the Constraction phase is the phase where the coding or algorithm is compiled according to the design. And the last is the Transition, which is the phase where the system has been completed and tested before the system can be used by the

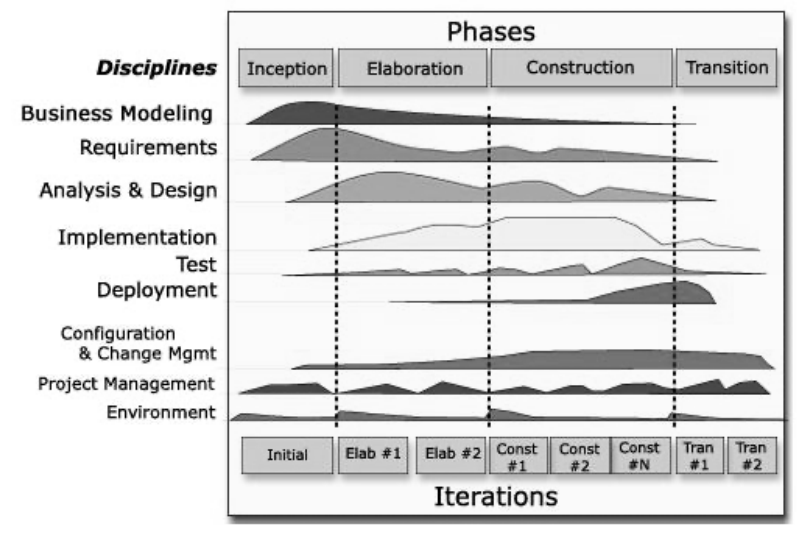

Fig 1. Relational unified process architecture. user.

\subsection{Black box testing method}

The blackbox testing method is a method for testing a system that has been completed before the system is launched to the market (Saleh et al., 2018). Blackbox testing only tests the functionality of a system, whether the system is running according to design or whether the system has a bug when a function is executed (Rahardja et al., 2018). As well as the blackbox also tests the external database structure whether it is appropriate or not with the expected outlines (Nugroho, 2008).

\section{RESULTS AND DISCUSSION}

\subsection{Result}

First of all, the police enter the application with the link http://etilang.me-gita.com/login to input the ticket form to traffic offenders. The police login by entering the correct username and password. Login veiw and main menu display shown in Fig. 2 and 3.

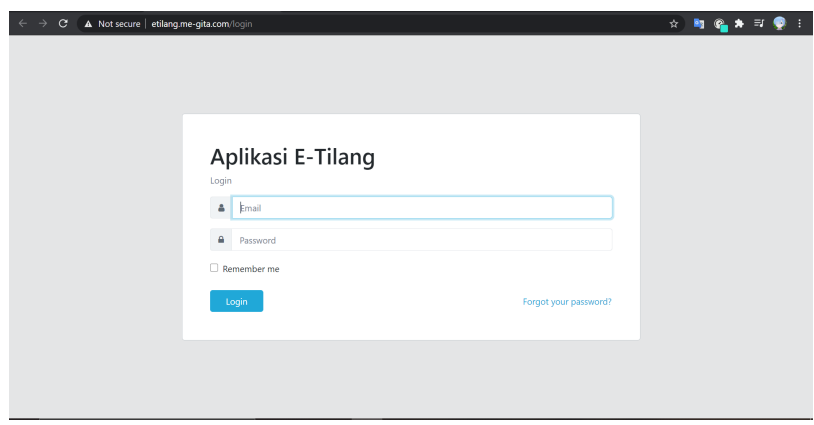

Fig 2. Login view.

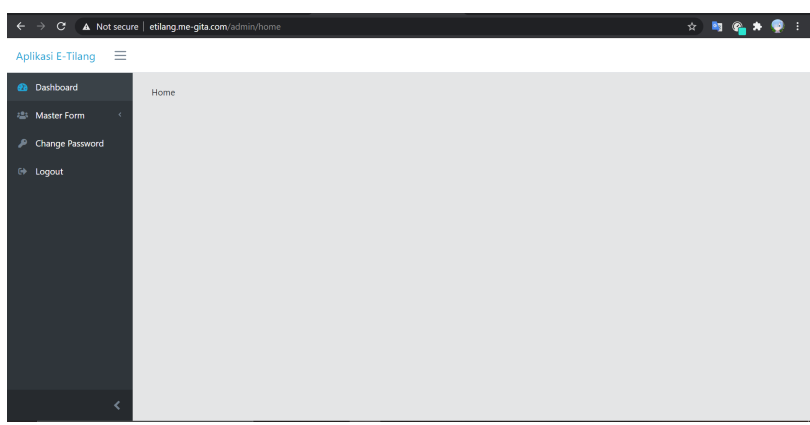

Fig 3. Main menu display.

After successful login, the system will redirect to the application dashboard, then the actor (police) enters the "Master Form" menu. There is a blue ticket form, a red ticket form, a warning ticket form and an online trial 


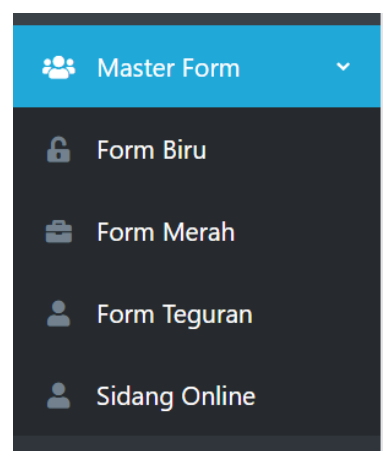

Fig 4. Master form.

The master form consists of a blue form, a red form, a warning form, and an online trial. Where each form has its own explanation below:

1) Blue form is a violation form in which the offender will get an account number to pay off the violation without going to the prosecutor's officel;

2) Red form is a violation form in which the offender is obliged to attend the trial and complete administration;

3) Warning form is a warning form for offenders who commit minor violations.

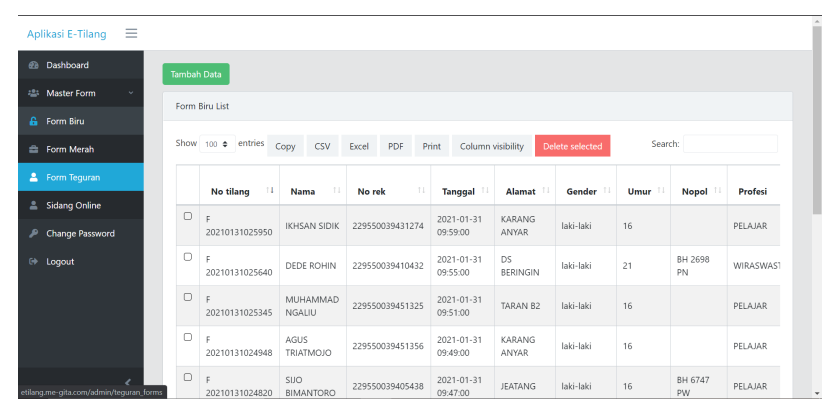

Fig 5. List of blue form offenders.

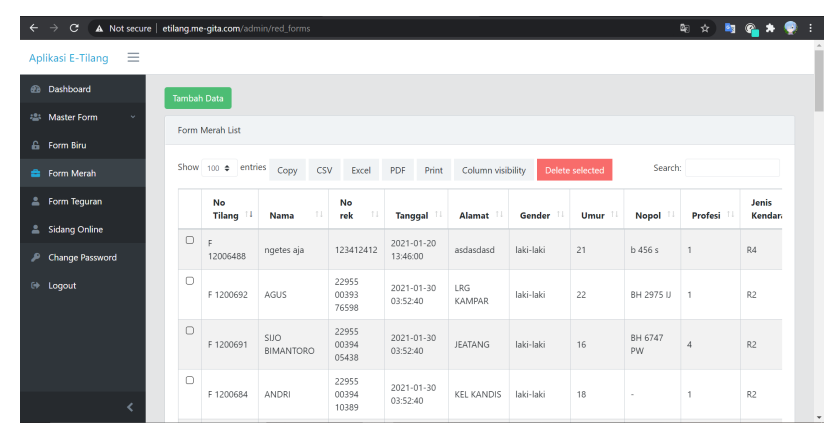

Fig 6. List of red form offenders.

As shown in Fig. 6 that a picture of the input form for each ticket form category, there is a blue ticket form which contains: Name, Account Number, Age, Profession, Offender, Vehicle Type, Police Number, Date of Violation, Address, Gender, Article, Type Confiscation, to save blue numbers the user can click save. The warning form contains: Warning to ?, name, age, profession of the offender, type of vehicle, police number, address, gender, article, to save the warning letter the user can click save.
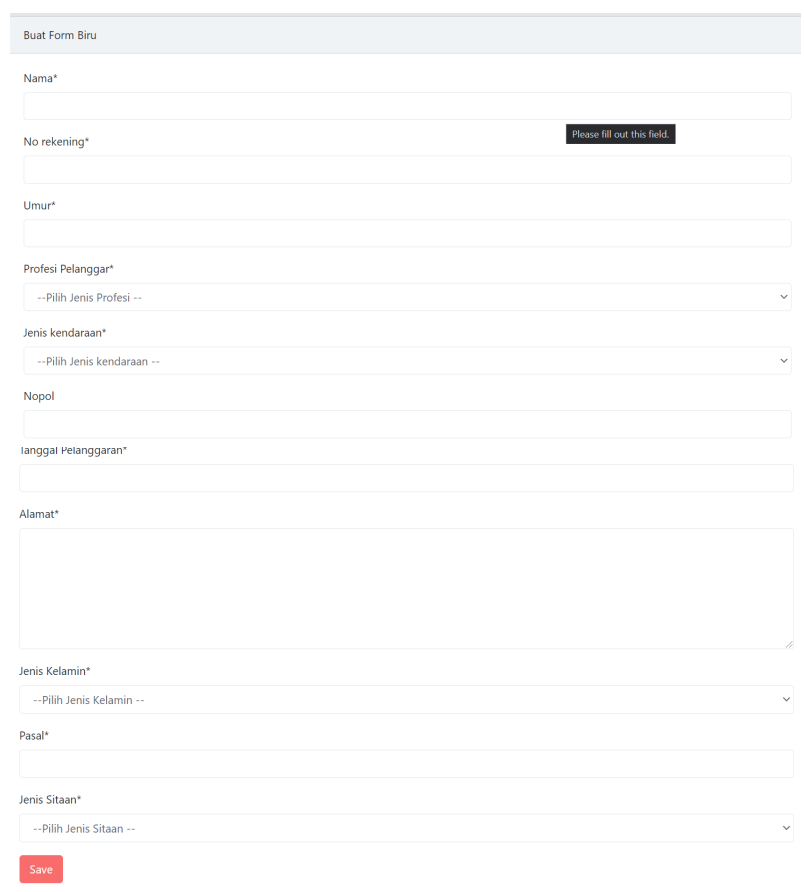

Fig 7. Blue ticket form.

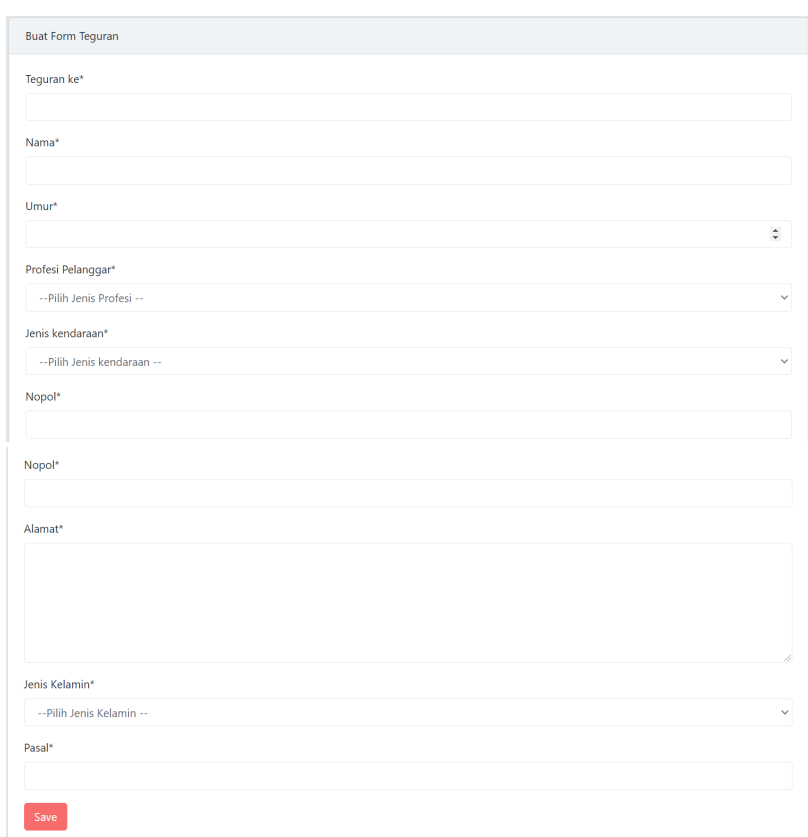

Fig 8. Warning form.

For the strike form, if the violator has received more than 1 reprimand, the system will automatically display the next warning if you have received a strike. And if the reprimand period has expired, then the offender will be moved to the blue or red form because the violation can no longer be categorized as a warning. Yang selanjutnya adalah untuk masyarakat. Masyarakat atau pelanggar yang terkena tilang dapat melihat hasil sidang atau hasil form tilang di web yang sudah disediakan oleh polisi. Dengan cara masuk ke website http://etilang.me-gita.com/ For the public or offenders who want to see the ticket form, it can be done by inputting the vehicle's police number, and the system will automatically display the description according to the vehicle's police number. The image below is an image of the ticket form on the website 
http://etilang.me-gita.com/.

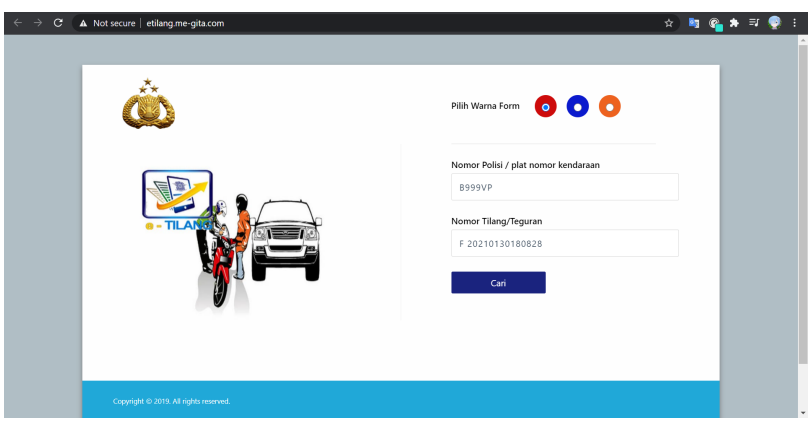

Fig 8. User view.

Figure 3.7 shows the page where the user (community) looks for a police number, primary is to find user data by entering the user's vehicle police number. In the picture above the writer enters the number, namely BH 2963 PU. Then the user just needs to click search and the system will display the violator ticket form.

\begin{tabular}{|c|c|c|}
\hline \multicolumn{2}{|c|}{ F 20210130180828} & $x$ \\
\hline Nopol & : B 999 VP & \\
\hline Nama & : ST HADJAR ANNISAA & \\
\hline Jenis Kelamin & : perempuan & \\
\hline Alamat & : fafasf & \\
\hline Profesi & : WIRASWASTA & \\
\hline Umur & : 23 tahun & \\
\hline Pelanggaran Pasal & $: 12$ & \\
\hline Tanggal Pelanggaran & : 2021-01-30 18:08:28 & \\
\hline Sitaan & : STNK & \\
\hline
\end{tabular}

Fig 9. Ticket result.

As shown in Fig. 9, a display of the offender's ticket form, where on that page there is data in the form of a police number, BRI VA account number, the violator's name, the violator's address, gender, age, profession, articles and confiscated items.

\subsection{Discussion}

After passing the design and coding phase, it was found that the application helps the police in inputting ticket forms. So that the data uploaded to the database is realtime data. And the letter of numbering can be processed directly by the administration on the same day because it is realtime data. In addition, the application is useful and useful for the public or traffic offenders because of the time savings in the trial ticket results. So far, the system is still conventional, from the conventional system it causes a lot of time wasted both in terms of police and society.

The application work process flow starts from the police entering the Android application and inputting the ticket form based on the form category, then the system will save the data to the database. Next is the public, the public or offenders who want to see the ticket form data through the web, namely http://etilang.me-gita.com/. Where in this application the public is only asked to enter the vehicle's police number and the system automatically displays a description according to the police number (see Table 1).

Table 1. Comparison of old and new systems.

\begin{tabular}{cc}
\hline Old System & New System \\
\hline There is no computerized & $\begin{array}{c}\text { An electronic } \\
\text { ticketing system has } \\
\text { been established }\end{array}$ \\
\hline $\begin{array}{c}\text { Submission of ticket } \\
\text { documents is still } \\
\text { conventional }\end{array}$ & $\begin{array}{c}\text { Submission of trial } \\
\text { files is done through } \\
\text { the application }\end{array}$ \\
\hline $\begin{array}{c}\text { The data reaches the } \\
\text { administration within hours } \\
\text { before the end of the work } \\
\text { period }\end{array}$ & $\begin{array}{c}\text { Data arrive on time } \\
\text { and during working } \\
\text { hours }\end{array}$ \\
\hline
\end{tabular}

\section{CONCLUSION AND FUTURE WORK}

The e-ticketing application starts from planning to identify problems, the system is running, user needs to design UML, database, and GUI which is named E-Tilang web-based to make it easier to identify traffic violations in Merangin Regency. This application focuses on recording violation tickets and the results that can be viewed on the web. Based on this study, it is able to facilitate the calculation and processing of numbers for both the Kasatlanas and the general public in viewing the results of the selection trials because all activities are carried out online and the data is recorded in real-time in the database.

Based on these studies, the future work is for system development is that there is a method for data processing so that the form criteria data can be determined by the system automatically.

\section{ACKNOWLEDGMENT}

I hereby convey my deepest appreciation and gratitude to the honorable: Max Teja Ajie Cipta Widiyanto, S.Kom, M.Kom as Advisor I and Sely Karmila, S.Kom., M.Si as Supervisor II Who has provided instructions, suggestions and guidance so that this thesis can be completed. Thank you for the same, I convey to IPDA Bakri as Head of Traffic Accidents Unit (KANIT LAKA), IPDA Gaol Elvis as a Traffic Patrol Officer and AIPDA Hendri Purnomo as NCO (BAUR) who has permitted to conduct experiments at the Merangin Police. 


\section{REFERENCES}

Al-Bahra. (2004). Perancangan Database Menggunakan Mysql. Yogyakarta: Andi Publisher.

Andre. (2019). Tutorial Belajar PHP Part 1: Pengertian dan Fungsi PHP dalam Pemrograman Web. Retrieved February 23, 2020, from https:/www.duniailkom.com/pengertian-danfungsi-php-dalam-pemograman-web/

Azis, A., \& Utami, D. A. B. (2018). Prototype ( eM Tilang ) Tilang Kendaraan Bermotor Berbasis Mobile Phone ( Android ) Guna Proses Tilang pada Kendaraan Bermotor di Purwokerto Kabupaten Banyumas. Jurnal Riset Sains Dan Teknologi, 2(2), $51-61$.

Andi. (2006). Pengolahan Database Dengan Mysql. Semarang: Yogyakarta, Andi dan Wahana Komputer.

Nugroho, B. (2008). Latihan Membuat Aplikasi Web PHP dan MySQL dengan Dreamweaver. Yogyakarta: Penerbit Gava Media.

Rahardja, U., Lutfiani, N., \& Alpansuri, M. S. (2018). Pemanfaatan Google Formulir Sebagai Sistem Pendaftaran Anggota Pada Website Asosiasi. Jurnal Media Informatika Budidarma, 2(4), 123. https://doi.org/10.30865/mib.v2i4.789

Saleh, A., Ariamin, A., Pawennari, A., \& Padhil, A. (2018). Perancangan Sistem Informasi Manajemen Administrasi Penjualan Pada Toko Lintang Outdoor Berbasis Web. Journal of Industrial Engineering Management, $3(1), \quad 15$. https://doi.org/10.33536/jiem.v3i1.199 